\title{
TCEA1 wt Allele
}

National Cancer Institute

\section{Source}

National Cancer Institute. TCEA1 wt Allele. NCI Thesaurus. Code C97823.

Human TCEA1 wild-type allele is located in the vicinity of $8 q 11.2$ and is approximately 56 $\mathrm{kb}$ in leng th. This allele, which encodes transcription elong ation factor A protein 1 , plays a role in transcriptional elong ation. A chromosomal insertion ins(8)(q12;q11q11) of this gene and the PLAG1 gene may be associated with salivary gland pleomorphic adenoma. 